
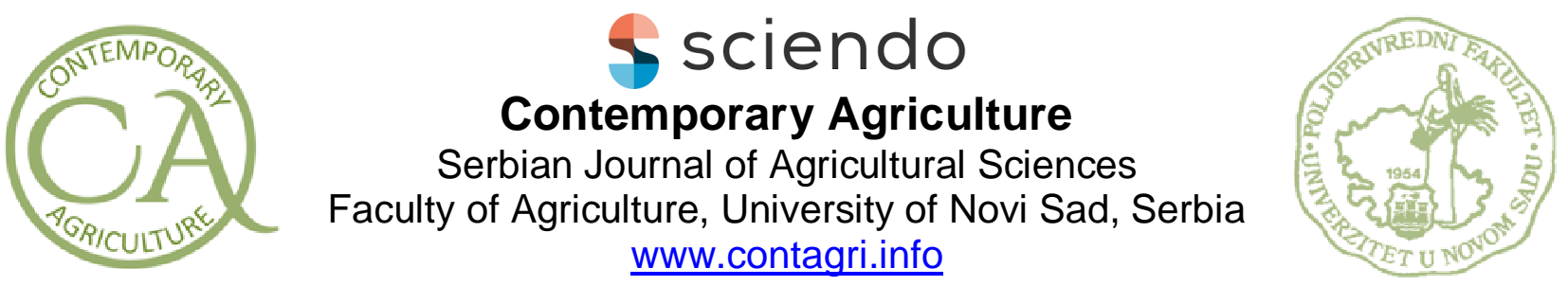

Original scientific paper

UDC: 631

DOI: $10.2478 /$ contagri-2021-0018

\title{
CHLOROPHYLL FLUORESCENCE AND DROUGHT TOLERANCE IN A MAPPING POPULATION OF DURUM WHEAT
}

\author{
CHAFIA LAROUK ${ }^{1,2 *}$, FATIMA GABON ${ }^{3}$, ZAKARIA KEHEL ${ }^{4}$, ABDELHAMID DJEKOUN ${ }^{2}$, \\ MILOUDI NACHIT ${ }^{4}$, AHMED AMRI \\ ${ }^{1}$ University of Batna 2, Department of Ecology and Environment, Batna 05078, Algeria \\ ${ }^{2}$ Laboratory of Genetics, Biochemistry and Plant Biotechnology, University of Constantine 1, Constantine 25000, \\ Algeria. \\ ${ }^{3}$ National Institute of Agronomic, Research, Biotechnology Research Unit, Rabat 1010, Morocco \\ ${ }^{4}$ ICARDA, Biodiversity and Integrated Gene Management, Rabat, Morocco \\ *Corresponding author: c.larouk@univ-batna2.dz
}

\begin{abstract}
SUMMARY
This study was conducted to compare and estimate the genetic variability among durum wheat lines in response to drought according to their grain yields and physiological traits. The use of fluorescence parameters as drought selection criteria for durum wheat was investigated in a population of 249 recombinant inbred lines (RILs) derived from a cross between two cultivars of durum wheat: 'Svevo' and 'Kofa'. The durum wheat RILs considered were analyzed to determine the relationship between their grain yields and chlorophyll fluorescence parameters at the grain filling stage under drought stress (rainfed) and supplemental irrigation (irrigated) conditions during the 2004 and 2005 seasons at the ICARDA center. The results obtained show that the durum wheat line performance was influenced by drought stress, indicating significant differences between the grain yields and fluorescence parameters recorded under drought rainfed $(R F)$ and irrigation $(I R)$ conditions. Significant differences between the experimental groups of durum wheat RILs $(P<0.05)$ were only recorded under drought conditions, with the exception of leaf water potential (Lwp). Under such conditions, nearly all the parameters examined were significantly increased in the highyielding group (with the exception of the Que parameter), thus revealing the genetic variability of the durum wheat lines considered in response to drought stress. The potential quantum efficiency of photosystem II $\left(F_{\downarrow} / F_{m}\right)$ was found to be positively associated with the grain yield parameter. The mean values of $F_{1} / F_{m}$ in both the high-and lowyielding groups significantly dropped under drought stress (0.71 and 0.68 , respectively) compared to the $\mathrm{Fv} / \mathrm{Fm}$ values recorded under irrigated conditions (0.80 and 0.81). Under drought conditions, slopes were highly significant $(P<0.001)$ nearly for all the fluorescence parameters examined (with the exception of CHLSPAD) compared to those recorded under irrigation conditions. It was concluded that chlorophyll content $(S P A D), F_{0}, F_{m}, F_{v}, F_{v} / F_{m}, L w p$, and Que could be used as additional indicators in screening wheat germplasm for drought tolerance.
\end{abstract}

Key words: agriculture, fluorescence, chlorophyll content, drought, durum wheat, yield

Abbreviations: GY - grain yield; HGY - high-yielding; IR - irrigated; Ks - kofasvevo; LGY - low-yielding; RILs recombinant inbred lines; RF - rainfed drought condition; CHLSPAD - Chlorophyll content SPAD

\section{INTRODUCTION}

Durum wheat (Triticum turgidum L. ssp durum) belongs to tetraploid species and is mainly cultivated in North Africa and the great plains of North America (Habash et al., 2009). The durum wheat produced in the Mediterranean basin accounts for $50 \%$ of the world durum wheat production (Sukumaran et al., 2018). However, durum wheat can 
potentially be a subject of many environmental constraints which can have adverse effects on its yield and yield stability (Mohammadi et al., 2018). Over the past years, durum wheat production has been fluctuating significantly due to climate change and drought in particular (Boussakouran et al., 2019). Drought stress affects the grain yield of cereals around the word (Abou-Elwafa, 2016). Due to the irregularity of rainfall, water scarcity becomes a limiting factor in the development cycle of cereals, causing yield losses in Mediterranean environments (Dolferus et al., 2011; Honsdorf et al., 2017). A number of studies conducted in the Mediterranean regions subject to water stress were based on the use of physiological traits as selection criteria to improve the yield of durum wheat (González-Ribot et al., 2017). Inadequate environmental conditions such as drought can cause morphological, biochemical, molecular and physiological disturbances in plants (Farooq et al., 2009; Yu et al., 2017). During the grain filling phase, drought can inflict considerable durum wheat yield losses (Maccaferri et al., 2008). Numerous tools are used to assess the drought tolerance of durum wheat. Chlorophyll content and fluorescence are alternative, non-destructive, simple, inexpensive, and rapid methods for assessing the physiological state of crops (Kalaji et al., 2016). Chlorophyll fluorescence is a good indicator of photosynthetic activity (Goltsev et al., 2016). Photosynthesis is sensitive to environmental constraints (Kalaji et al., 2012). Chlorophyll fluorescence is mostly used as a parameter for assessing the plant's abiotic stresses tolerance. It is also an effective indicator of the photosynthetic process under stress (Stirbet et al., 2018; Simeneh, 2020) as drought stress reduces the plant's photosynthetic capacity by affecting its productivity. Plant breeding should be based on identifying good performing genes by means of chlorophyll fluorescence (Simeneh, 2020). Moreover, chlorophyll fluorescence is considered an important tool for examining the photochemical efficiency of leaves, and represents an interesting new approach to the selection of plant breeding programs (Baker \& Rosenqvist., 2020). Under adverse environmental conditions such as drought, fluorescence measurements estimate plant vitality by detecting changes in photosystem components (PSII), electron transport chain, and photochemical reactions (Dabrowski et al., 2016). Drought acts on the PSII reaction centers of the photosynthetic system and the stomata (Paknejad et al., 2007), thus inducing reductions in grain yields (Jedmowski et al., 2013). Mohammadi et al. (2018) argue that fluorescence measurements can help improve the overall agricultural productivity and grain yield of durum wheat under fluctuating climatic conditions. Direct and indirect changes in fluorescence induction kinetics following abiotic stress have been studied in a number of crops (Baker et al., 2001). In wheat, chlorophyll fluorescence is used as a suitable tool to understand photosynthetic metabolism and examine drought tolerance (Guha et al., 2013). A decrease in chlorophyll content in stressed plants is considered one of the major causes of reduced growth and productivity (Guerfel et al., 2009; Ghobadi et al., 2011). Under water stress, chlorophyll content is linked to grain yield in durum wheat (Khayatnezhad et al., 2011). In breeding programs, chlorophyll content has been used as an easy-to-use and cost-effective indirect breeding method for improving water use efficiency in common wheat (Fotovat et al., 2007). According to Bogale-Gonfa et al. (2011), significant differences were found between durum wheat varieties which are tolerant to water stress and those which are sensitive to water stress. The varieties tolerant to water stress (characterized by high leaf water potential) exhibited higher turgor potential, photosynthesis rates, grain yields and chlorophyll contents with decreased rates of transpiration (Anjum et al., 2011; Tardieu et al., 2014).

The present study aims at using fluorescence as a breeding selection criterion based on drought tolerance in order to improve durum wheat grain yields under water-limited Mediterranean conditions. The physiological responses of durum wheat exposed to water stress were assessed (i), the performance of chlorophyll fluorescence kinetics was evaluated under field conditions (ii), and a chlorophyll fluorescence parameter was identified as a drought tolerance test for durum wheat (iii).

\section{MATERIAL AND METHODS}

\section{Plant material}

This study was carried out as part of the breeding program conducted throughout the Mediterranean basin, namely "Project IDuWUE, Improving Durum Wheat for Use Efficiency and Yield Stability". A population of 249 recombinant inbred lines (RILs), elaborated by Società Produttori Sementi (Bologna, Italy, the generation F7 from a cross of two cultivars of durum wheat 'Kofa $\times$ Svevo'), were examined in the study. 'Kofa' and 'Svevo' are two cultivars which are well adapted to the Mediterranean climate and characterized by early flowering.

The 'Kofa' cultivar is native to the Southwestern United States, published by Western Plant Breeders (Arizona, USA). This cultivar is obtained from a population based on cross parents (dicoccum alpha pop-85 S-1).

The 'Svevo' cultivar originated in Italy and was produced in 1996 by Società Produttori Sementi obtained from the crossing of the advanced 'CIMMYT' line and the 'Zenit' cultivar developed from a cross between Italian and American accessions. 
The 'Vitron' cultivar is a high-yielding cultivar adapted to the Mediterranean conditions, developed from 'CIMMYT' germplasm (cross Jori/Anhinga//Flamingo) and established in 1985 (Pfeiffer et al. 2000) (Maccaferri et al., 2008).

\section{Experimental design}

Over a period of 2 years, a total of eight field trials were carried out (4 trials in 2004 and 4 trials in 2005) in two Mediterranean countries: Syria and Lebanon (at the experimental station of the ICARDA centre (the International Center for Agricultural Research in the Dry Area, Aleppo, Syria), Tel Hadya (Syria) and Terbol (Libanon)). All 249 lines considered were evaluated under irrigation (IR) and rainfed drought conditions (RF). The RILs of the 'Kofa', 'Svevo' and 'Vitron' cultivars were tested in unreplicated field trials, adopting an augmented design (Federer, 1956; Peterson, 1985) as a field experimental scheme with three checks per each row of the field scheme. The experimental plot size was $4 \mathrm{~m}^{2}$, sown in 20 rows of $2.5 \mathrm{~m}$ in length, with an inter-row spacing of $30 \mathrm{~cm}$. The experimental site was characterized by two environments with different water regimes: rainfed (RF) and irrigated (IR). Prior to sowing, seed viability was determined on a sample of 100 seeds/RIL. The seeds were treated with fungicides (Vitavax FLO NF) in order to avoid contamination by external pathogens, whereas weeds were controlled according to the standards of agricultural practice recommended for both environments. The sowing was performed using 100 grains of each line considered. During the critical phase of grain filling, a supplemental irrigation of 25-30 mm was applied. The precipitation rates recorded were $277.6 \mathrm{~mm}$ and $245.5 \mathrm{~mm}$ in 2004 and 2005, respectively. Grain yields $(\mathrm{GY})(\mathrm{kg} / \mathrm{ha})$ were estimated for two experimental groups of 40 lines each (namely high- and low-yielding groups) in both irrigated and rainfed environments to assess differences in the fluorescence parameters between the two groups considered.

\section{Study site characteristics}

Tel Hadya (Syria) is the main station at the ICARDA center, located in the southwest of the city of Aleppo in Syria (Latitude $36^{\circ} 01^{\prime} \mathrm{N}$, longitude $36^{\circ} 56^{\prime} \mathrm{E}, 284 \mathrm{~m}$ a.s.l.). The soil of Tel Hadya is composed of clay, montmorillonite with a pH varying between 7.9 and 8 , thermal (the average annual temperature at $5 \mathrm{~cm}$ depth is 15 to $22{ }^{\circ} \mathrm{C}$ ) and Xerochrept Calcixerollique or Calcixerert chromic. According to the old classification of soil sciences, the soil is classified as Terra Rosa (United States) or red Mediterranean soils (France).

\section{Experimental analysis}

Fluorescence parameters such as $\mathrm{F}_{0}, \mathrm{~F}_{\mathrm{v}}, \mathrm{F}_{\mathrm{m}}$, and $\mathrm{F}_{\mathrm{v}} / \mathrm{F}_{\mathrm{m}}$ were obtained using a fluorimeter (Model Hansatech RS232C) developed by Schreiber et al. (1986). Applying short pulses of red light $\left(\mathrm{L}_{0}\right)$ at a very low frequency determined the initial fluorescence $\left(\mathrm{F}_{0}\right)$, followed by a second-high intensity white light $\left(\mathrm{L}_{1}\right)$. This light induces the induction of Kautsky kinetics. The use of double illumination by sending short flashes of white light (pulse saturation) enables the maximum fluorescence $\left(\mathrm{F}_{\mathrm{m}}\right)$ to be determined.

The calculated parameters were as folows:

Variable fluorescence $(\mathrm{Fv}): \mathrm{F}_{\mathrm{v}}=\mathrm{F}_{\mathrm{m}}-\mathrm{F}_{0}$

Photochemical quenching (Que): Que $=\mathrm{F}_{0} / \mathrm{F}_{\mathrm{v}}$

Photochemical efficiency or quantum efficiency $(\mathrm{EP})$ : $\mathrm{EP}=\mathrm{F}_{\mathrm{V}} / \mathrm{F}_{\mathrm{m}}$

Leaf water potential (Lwp): $\mathrm{Lwp}=\mathrm{F}_{\mathrm{m}} / \mathrm{F}_{0}$

The chlorophyll content was determined on the Zadoks 70 scale using a chlorophyll meter (the MINOLTA model of the SPAD type) (Zadoks et al., 1974).

\section{Statistical analysis}

The data obtained were analyzed using the analysis of variance (ANOVA) and the GLM procedure. Multiple comparisons of the parameter means computed were performed using the smallest significant difference LSD at 5\% for all the parameters studied. These analyses were performed with the statistical software SAS version 9.1 (SAS Institute Inc., Cary, NC., USA). A linear regression was calculated to determine the relationship between the grain yield and chlorophyll fluorescence parameters. The linear regression lines were adjusted by Excel 2010. The correlation analysis was used to assess the relationship between different fluorescence parameters (the Pearson correlation coefficients). The correlations and distributions of the variables were obtained using the Genstat version 18 software. 


\section{RESULTS AND DISCUSSION}

\section{Correlation between yield-related physiological traits}

The present study confirmed that all of the correlation coefficients obtained for the grain yields (GY) and fluorescence parameters of the durum wheat RILs considered were significant under drought conditions (Tab. 1), which is consistent with the findings of Araus et al. (1998). In contrast to a study reporting a rather positive correlation between grain yields and chlorophyll contents in bread wheat under drought conditions (Paknejad et al., 2007), the results obtained herein show a positive and significant correlation between the quantum yield Fm/Fv and the CHLSPAD $\left(\mathrm{r}=0.146^{*}\right)$ (which is consistent with the findings of Avenson et al. (2005) and Almeselmani et al. (2015). Chlorophyll contents were found to be in a positive correlation with photosynthetic rates. However, a strong positive correlation was observed only between the GY and CHLSPAD values under irrigation conditions $(\mathrm{r}=$ $\left.0.302^{* * *}\right)$, whereas the CHLSPAD recorded was found to be negatively correlated with Que $\left(-0.116^{*}\right)$ (Tab. 3).

Table1. Correlation coefficients of the fluorescence parameters considered under drought conditions during 2004 and 2005 seasons

\begin{tabular}{|c|c|c|c|c|c|c|c|c|}
\hline & & $\mathbf{F}_{0}$ & $\mathbf{F}_{\mathbf{m}}$ & $\mathbf{F}_{\mathbf{v}}$ & $\mathbf{F}_{\mathrm{v}} / \mathbf{F}_{\mathrm{m}}$ & Que & Lwp & CHLSPAD \\
\hline \multirow{7}{*}{$\begin{array}{l}\text { Drought } \\
\text { (RF) }\end{array}$} & $\mathrm{F}_{\mathrm{m}}$ & $0.213^{* * *}$ & & & & & & \\
\hline & $\mathrm{F}_{\mathrm{v}}$ & $0.009^{\mathrm{ns}}$ & $0.979^{* * *}$ & & & & & \\
\hline & $\mathrm{F}_{\mathrm{v}} / \mathrm{F}_{\mathrm{m}}$ & $-0.601^{* * *}$ & $0.638^{* * *}$ & $0.778^{* * *}$ & & & & \\
\hline & Que & $0.600^{* * * *}$ & $-0.617^{* * *}$ & $-0.757^{* * *}$ & $-0.993 * * *$ & & & \\
\hline & Lwp & $-0.581^{* * *}$ & $0.657^{* * *}$ & $0.793^{* * *}$ & $0.972 * * *$ & $-0.944 * * *$ & & \\
\hline & CHLSPAD & $0.282^{* * *}$ & $0.093^{\mathrm{ns}}$ & $0.037^{\mathrm{ns}}$ & $-0.146^{*}$ & $0.146^{*}$ & $-0.147 *$ & \\
\hline & GY & $-0.230^{* * *}$ & $0.364^{* * * *}$ & $0.420^{* * *}$ & $0.503 * * *$ & $-0.507 * *$ & $0.468 * *$ & $-0.062 \mathrm{~ns}$ \\
\hline \multirow{7}{*}{ Irrigation (IR) } & $\mathrm{F}_{\mathrm{m}}$ & $0.230 * *$ & & & & & & \\
\hline & $\mathrm{F}_{\mathrm{v}}$ & $0.089 \mathrm{~ns}$ & $0.990 * * *$ & & & & & \\
\hline & $\mathrm{F}_{\mathrm{v}} / \mathrm{F}_{\mathrm{m}}$ & $-0.404 * * *$ & $0.768 * * *$ & $0.841 * * *$ & & & & \\
\hline & Que & $0.394 * * *$ & $0.734 * * *$ & $-0.806 * * *$ & $-0.990 * * *$ & & & \\
\hline & Lwp & $-0.403 * * *$ & $0.795 * * *$ & $0.869 * * *$ & $0.956^{* * *}$ & $-0.909 * * *$ & & \\
\hline & CHLSPAD & $-0.058 \mathrm{~ns}$ & $0.081 \mathrm{~ns}$ & $0.093 \mathrm{~ns}$ & $0.140 \mathrm{~ns}$ & -0.116 & $0.107 \mathrm{~ns}$ & \\
\hline & GY & $0.091 \mathrm{~ns}$ & $0.017 \mathrm{~ns}$ & $0.004 \mathrm{~ns}$ & $-0.019 \mathrm{~ns}$ & $0.017 \mathrm{~ns}$ & $-0.043 \mathrm{~ns}$ & $0.302 * * *$ \\
\hline
\end{tabular}

Significant positive correlations were found between $G Y$ and $F_{m}, F_{v}, F_{v} / F_{m}$, Que, and Lwp under drought conditions, whereas the correlation of GY with Que $\left(-0.507^{* *}\right)$ and the aforementioned parameters was negative and significant (Tab. 1). A recent study on triticale and wheat at anthesis and grain filling reported a positive and significant correlation between GY and fluorescence parameters (Méndez-Espinoza et al., 2019).

Under drought conditions, $F_{0}, F_{m}, F_{v}$, Que, Lwp and GY were found to have the highest correlation with $F_{v} / F_{m}$, $(r=-$ $0.601 * * *, 0.638 * * *, 0.778 * * *,-0.993 * * *, 0.972 * * *$ and $0.503 * * *$, respectively). Balouchi (2010) and Mohammadi et al. (2019) revealed that some parameters of fluorescence, such as the maximum quantum yield of PS II ( $\left.F_{v} / F_{m}\right)$ and fluorescence $\left(\mathrm{F}_{0}\right)$, correlate with drought tolerance. However, the correlation between all fluorescence parameters and GY was generally higher and more significant under drought stress than under irrigated conditions (Tab. 3). The correlations between $\mathrm{F}_{\mathrm{v}}, \mathrm{F}_{\mathrm{m}}$, Lwp, and $\mathrm{F}_{\mathrm{v}} / \mathrm{F}_{\mathrm{m}}$ under irrigation conditions were similar to those obtained under drought conditions. The correlative analysis of plant's physiological and morphological traits can be used as the criteria for selecting tolerant genotypes under water deficit stress (Farshadfar et al., 2013).

\section{Grain yield and drought stress}

The analysis of variance performed revealed significant differences (data not shown) between the RILs considered relative to all the physiological parameters measured and grain yields (GY) produced under supplemental irrigation (IR) and drought conditions (RF). The average mean values of grain yield under drought and irrigation conditions were 3,558 and $5,844 \mathrm{~kg} / \mathrm{ha}$, respectively. The coefficient of variance $(\mathrm{CV})$ computed under drought conditions ranged from $4.35 \%$ (for $\mathrm{Fv} / \mathrm{Fm}$ ) to $23.08 \%$ (for grain yields). The highest value of $\mathrm{CV}$ under irrigation conditions 
was observed in the case of Que (28.07\%), whereas the lowest value of $7.96 \%$ was obtained for grain yields (GY). Our results show variability and genetic diversity in the durum wheat population considered under different water status.

Under drought stress, the grain yields ranged from 1,154 to $5,913 \mathrm{~kg} / \mathrm{ha}$ with a parental mean of $3,493 \mathrm{~kg} / \mathrm{ha}$. The Ks237 and Ks232 RILs produced the highest grain yields under drought conditions: 5,587 and 5,913 kg/ha respectively. However, the lowest grain yield of 2,667 kg/ha was recorded in the Ks095 RIL. A significant decrease in grain yields under drought stress was reported by González-Ribot et al. (2017), Etminan et al. (2019) and Qaseem et al. (2019). Under irrigation conditions, grain yields ranged from 3,918 to $8,192 \mathrm{~kg} / \mathrm{ha}$ with a parental mean of $5,846 \mathrm{~kg} / \mathrm{ha}$. The Ks239 RIL produced the lowest yield (3,918 kg/ha), whereas the highest yield of 7,800 kg/ha was recorded in the Ks149 RIL. Under drought conditions, these RILs produced 1,954 kg/ha of grain yield more than the parental mean calculated (Tab. 2). During the grain filling period, drought stress hinders photosynthesis, the relocation of assimilates and the transfer of stored substances into grains, which significantly decreases the grain yield (Ehdaie et al., 2006; Talebi et al., 2009; Dolferus et al., 2011; Pour-Aboughadareh et al., 2020).

Considerable RIL variations were found in both scenarios (rainfed and irrigated) for the highest and lowest yielding groups (HGY and LGY) (Tab. 2). When the RILs were allocated to high-yielding and low-yielding groups, negative effects of drought stress caused a significant reduction in a number of their physiological traits, thus exerting a damaging effect on their grain yields (Tab. 2). Similar results were reported by Roostaei et al. (2011) and Boussakouran et al. (2019). The mean values of grain yields under drought stress were $3,336 \mathrm{~kg} / \mathrm{h}$ and 4,976 kg/h for the LGY and HGY groups, respectively. Significant differences were recorded between the LGY and HGY groups relative to all physiological traits considered under supplemental irrigation compared to susceptible groups affected by drought stress (Tab. 2). The least significant difference (LSD) test confirmed that the RILs differed significantly according to the traits examined. Therefore, the LSD test results for GY in the irrigated and drought environments were 262 and 384.1, respectively. However, wheat growth under drought affects the plant's physiological and agronomic characteristics regardless of the genotype and the period of stress exposure (Talebi, 2011; Almeselmani, 2012; Liu et al., 2015; Méndez-Espinoza et al., 2019).

\section{The relationship between physiological traits and grain yields relative to drought tolerance}

The content of chlorophyll is a functional physiological trait used to estimate the effect of drought stress (Zhuang et al., 2020). Under both rainfed and irrigated conditions (Tab. 2), the results obtained show significant differences between the CHLSPAD and GY values recorded. As reported by other authors (Bijanzadeh \& Emam, 2010; Khayatnezhad et al., 2011; Almeselmani et al., 2012), one of the major causes of reduced growth and productivity is a decrease in the chlorophyll content of stressed plants. However, a significant variability in CHLSPAD was found between the HGY and LGY groups and the CHLSPAD mean value computed for the RILs considered. According to Izanloo et al. (2008) and Khadka et al. (2020), water deficit leads to a decrease in the chlorophyll content of wheat, which was also confirmed in our study. Under irrigated condition (Tab. 2), the RILs of both HGY and LGY groups exhibited higher values of CHLSPAD than those recorded under drought conditions. Moreover, it was found that the values of chlorophyll recorded under drought stress in both the HGY and LGY groups were 4,976 and 3,336 kg/ha, respectively (Tab. 2). Low amounts of CHLSPAD were also recorded under drought stress in both the HGY and LGY groups (49 and 40, respectively). Drought reduces the plant's chlorophyll content and photosynthetic pigments. Abdipur et al. (2013) and Allahverdiyev et al. (2015) showed that the content of chlorophyll is positively related to the rate of photosynthesis. A reduction in chlorophyll content will directly lead to the inhibition of photosynthetic potential, thus affecting the grain yield. Other studies have also reported that the loss in chlorophyll depends on the reduced expression of genes encoding enzymes for chlorophyll biosynthesis (Liu et al., 2017).

Leaf water potential was used to estimate the plant's water status. The values obtained show significant differences between the HGY and LGY RILs under drought stress and under irrigation conditions (Tab. 2), ranging from 3 to 5 respectively. However, our results are consistent with the findings of Liu et al. (2015), who reported significant reductions in leaf water potential in the seven durum wheat genotypes considered due to pre-anthesis water deficit stress. The shortage of soil moisture diminishes the water potential of leaves, which causes a reduction in turgor and photosynthetic activity, ultimately reducing plant growth and yield production. Siddique et al. (2000) argued that changes in the plant's Lwp are related to changes in osmotic pressure.

Fluorescence parameters $\left(F_{0}, F_{v}, F_{m}, F_{v} / F_{m}\right.$ and Que) can be used as essential physiological markers for assessing the photosynthetic activity of PSII in plants under abiotic stress (Feng et al., 2017; Pour-Aboughadareh et al., 2020) and as a tool to screen plant's genotypes for drought tolerance (Paknejad et al., 2007; Kalaji et al., 2016).

In this experiment, differences between the RIL groups were significant $(\mathrm{P}<0.05)$ only under drought conditions, with the exception of leaf water potential (Lwp). Under these conditions, all the parameters observed increased 
significantly in the high-yielding group (with the exception of the Que parameter (Tab. 1), revealing a genetic variability in response to drought stress. As shown in Table 2, there was no difference in the genetic variability between the RILs of both HGY and LGY groups and the control in the supplemental irrigation environment. The results obtained show that the greatest values of $F_{0}$ for both the high-yielding and control lines were recorded under stress conditions compared to those recorded under irrigation condition (Tab. 2). These results are congruent with the findings of Nori et al. (2011) and Wang et al. (2016). The study carried out by Schansker et al. (2014) showed that reductions in the quantity of quinine (QA) at the level of PSII induce an increase in $\left(\mathrm{F}_{0}\right.$ and $\left.\mathrm{F}_{\mathrm{m}}\right)$ fluorescence. According to Havaux et al. (1998), the $\mathrm{F}_{0}$ value variations reflect the destruction of the PSII reaction centers, thus causing a decrease in the efficiency of the photochemical reactions of PSII under stress conditions. The high- and low-yielding groups considered herein exhibited lower Fm values under drought conditions than the control Fm values and those recorded under irrigation conditions (Tab. 2).

As reported by other authors, the measurement of fluorescence $\left(\mathrm{F}_{\mathrm{m}}\right)$ is a complex trait associated with the endogenous structure of the leaf (Kalaji et al., 2016). This structure possesses cellular and molecular characteristics which can be used to determine the absorption of actinic light, the reflection and the emission of the reabsorption of chlorophyll fluorescence in PSII, as well as the content of chlorophyll in the leaf. In the present study, the reduction in Fm may be related to a reduction in chlorophyll concentration observed in the RILs under drought stress (Tab. 2). Similar findings were reported by Khayatnezhad et al. (2011) and Paunov et al. (2018). The fluorescence parameters $\left(F_{0}, F_{m}, F_{v}\right.$, and $\left.F_{v} / F_{m}\right)$ decreased under water stress. The increase in the $F_{0}$ values and the decrease in the $F_{m}$ values occurred concomitantly with the decrease in the $\mathrm{F}_{\mathrm{v}} / \mathrm{F}_{\mathrm{m}}$ values, which is clearly visible in the highest and lowest yielding lines under drought stress compared to same groups under irrigation conditions. Similar findings were reported in previous studies by Roostaei et al. (2011), Papageorgiou \& Govindjee (2011) and Wang et al. (2016).

Table 2. Fluorescence parameter means for all the genotypes, parents, and highest and lowest yielding groups under drought (RF) and supplemental irrigation conditions (IR) during the seasons considered

\begin{tabular}{|c|c|c|c|c|c|c|c|c|c|}
\hline & Group/Genotype & $\mathbf{F}_{\mathbf{0}}$ & $\mathbf{F}_{\mathrm{m}}$ & $\mathbf{F}_{\mathbf{v}}$ & $\mathbf{F}_{\mathrm{v}} / \mathbf{F}_{\mathrm{m}}$ & Que & Lwp & CHL & GY \\
\hline \multirow{11}{*}{$\begin{array}{l}\text { Drought } \\
\text { conditions }\end{array}$} & Means & 670 & 3273 & 2603 & 0.79 & 0.26 & 4.95 & 54.18 & 3494 \\
\hline & SD & \pm 85.59 & \pm 420.94 & \pm 411.34 & \pm 0.03 & \pm 0.06 & \pm 0.76 & \pm 4.38 & \pm 1055 \\
\hline & Maximum & 1052 & 4079 & 3306 & 0.84 & 0.57 & 6.36 & 63.8 & 5480 \\
\hline & Minimum & 368 & 1373 & 1005 & 0.63 & 0.18 & 2.75 & 42 & 1154 \\
\hline & $\begin{array}{l}\text { Mean for } 40 \text { highest yielding lines } \\
\text { SD }\end{array}$ & $\begin{array}{c}901^{\mathrm{b}} \\
\pm 12.01\end{array}$ & $\begin{array}{l}3210^{\text {ba }} \\
\pm 70.77\end{array}$ & $\begin{array}{r}2309^{\mathrm{a}} \\
\pm 71.52\end{array}$ & $\begin{array}{l}0.71^{\text {ba }} \\
\pm 0.007\end{array}$ & $\begin{array}{c}0.39^{\text {ba }} \\
\pm 0.014\end{array}$ & $\begin{array}{l}3.60^{\mathrm{a}} \\
\pm 0.095\end{array}$ & $\begin{array}{l}49.34^{\mathrm{b}} \\
\pm 0.54\end{array}$ & $\begin{array}{r}4976^{\mathrm{a}} \\
\pm 49.40\end{array}$ \\
\hline & $\begin{array}{l}\text { Mean for } 40 \text { lowest yielding lines } \\
\text { SD }\end{array}$ & $\begin{array}{r}873^{\mathrm{c}} \\
\pm 8.51\end{array}$ & $\begin{array}{l}2740^{\mathrm{bc}} \\
\pm 54.71\end{array}$ & $\begin{array}{l}1866^{\mathrm{ba}} \\
\pm 53.13\end{array}$ & $\begin{array}{c}0.68^{\mathrm{a}} \\
\pm 0.006\end{array}$ & $\begin{array}{c}0.46^{\mathrm{b}} \\
\pm 0.005\end{array}$ & $\begin{array}{c}3.13^{\mathrm{a}} \\
\pm 0.097\end{array}$ & $\begin{array}{l}40.2^{\mathrm{a}} \\
\pm 0.60\end{array}$ & $\begin{array}{r}3336^{\mathrm{b}} \\
\pm 36.33\end{array}$ \\
\hline & Svevo & $808^{\mathrm{c}}$ & $3106^{\mathrm{c}}$ & $2298^{b}$ & $0.73^{\mathrm{ba}}$ & $0.35^{\mathrm{ba}}$ & $3.93^{\mathrm{a}}$ & $53.24^{\mathrm{a}}$ & $3428^{b}$ \\
\hline & Kofa & $714^{\mathrm{a}}$ & $3439^{a}$ & $2726^{\mathrm{a}}$ & $0.78^{\mathrm{b}}$ & $0.27^{\mathrm{a}}$ & $4.81^{\mathrm{a}}$ & $55.12^{\mathrm{a}}$ & $3559^{\mathrm{b}}$ \\
\hline & Vitron & $749^{\mathrm{b}}$ & $3262^{\text {ba }}$ & $2513^{\mathrm{a}}$ & $0.77^{\mathrm{b}}$ & $0.28^{\mathrm{ba}}$ & $4.85^{\mathrm{a}}$ & $50.43^{\mathrm{b}}$ & $3570^{\mathrm{b}}$ \\
\hline & C.V.\% & 12.07 & 12.38 & 15.37 & 4.35 & 22.85 & 15.04 & 7.62 & 23.08 \\
\hline & LSD $5 \%$ & 35.15 & 179.7 & 178.2 & 0.0153 & 0.026 & 0.33 & 2.22 & 384.1 \\
\hline \multirow{13}{*}{$\begin{array}{l}\text { Irrigation } \\
\text { conditions }\end{array}$} & Means & 622 & 3099 & 2477.68 & 0.79 & 0.26 & 5.01 & 52.84 & 5846 \\
\hline & $\mathrm{SD}$ & \pm 71.25 & \pm 497.91 & \pm 486.50 & \pm 0.039 & \pm 0.07 & \pm 0.83 & \pm 5.73 & \pm 1009 \\
\hline & Maximum & 855 & 4061 & 3386 & 0.85 & 0.43 & 6.59 & 63.3 & 8192 \\
\hline & Minimum & 393 & 1407 & 1014 & 0.70 & 0.18 & 3.35 & 32.8 & 4553 \\
\hline & Mean for 40 highest yielding lines & $648^{\mathrm{a}}$ & $3311^{\mathrm{a}}$ & $2663^{\mathrm{a}}$ & $0.80^{\mathrm{a}}$ & $0.25^{\mathrm{a}}$ & $5.16^{\text {ba }}$ & $55^{\mathrm{a}}$ & $6778^{\mathrm{a}}$ \\
\hline & SD & \pm 8.06 & \pm 49.24 & \pm 49.53 & \pm 0.004 & \pm 0.006 & \pm 0.13 & \pm 0.64 & \pm 51.33 \\
\hline & Mean for 40 lowest yielding lines & $624^{\mathrm{a}}$ & $3290^{\mathrm{a}}$ & $2665^{\mathrm{a}}$ & $0.81^{\mathrm{a}}$ & $0.24^{\mathrm{a}}$ & $5.28^{\mathrm{a}}$ & $50^{\mathrm{c}}$ & $4557^{\mathrm{c}}$ \\
\hline & $\mathrm{SD}$ & \pm 9.78 & \pm 85.45 & \pm 84.81 & \pm 0.007 & \pm 0.011 & \pm 0.15 & \pm 1.148 & \pm 33.59 \\
\hline & Svevo & $618^{\mathrm{a}}$ & $2969^{b}$ & $2350^{\mathrm{b}}$ & $0.79^{\mathrm{a}}$ & $0.26^{\mathrm{a}}$ & $4.80^{\mathrm{b}}$ & $53^{\text {bac }}$ & $5888^{\mathrm{b}}$ \\
\hline & Kofa & $625^{\mathrm{a}}$ & $3229^{\mathrm{ab}}$ & $2605^{\text {ba }}$ & $0.80^{\mathrm{a}}$ & $0.24^{\mathrm{a}}$ & $5.16^{\text {ba }}$ & $53.6^{\text {ba }}$ & $5804^{\mathrm{b}}$ \\
\hline & Vitron & $621^{\mathrm{a}}$ & $3240^{\mathrm{ab}}$ & $2619^{\mathrm{a}}$ & $0.80^{\mathrm{a}}$ & $0.24^{\mathrm{a}}$ & $5.21^{\text {ba }}$ & $51.8^{\mathrm{bc}}$ & $6576^{\mathrm{a}}$ \\
\hline & C.V.\% & 11.32 & 15.21 & 18.49 & 4.92 & 28.07 & 16.06 & 10.38 & 7.96 \\
\hline & LSD 5\% & 40.2 & 277.1 & 271.2 & 0.02 & 0.04 & 0.47 & $\begin{array}{r}3.07 \\
<0.05\end{array}$ & 262 \\
\hline
\end{tabular}


The increase in the $F_{0}$ values and the decrease in the $F_{m}$ values under drought stress can be attributed to chronic photo-inhibition due to the photo-inactivation regulation of PSII reaction centers, and even the D1 protein damage (Oxboroug, 2004; Roostaei et al., 2011; Almeselmani et al., 2015; Mohammadi et al., 2019). Moreover, all these effects show that the photosynthetic process is strongly affected by drought stress (Paknejad et al., 2007). The analysis of variance performed shows a significant difference between the $F_{v} / F_{m}$ values under drought and irrigation conditions (Tab. 2). The mean values of $F_{v} / F_{m}$ in the high- and low-yielding groups under drought stress dropped markedly ( 0.71 and 0.68 , respectively). The results obtained indicate that the effectiveness measured decreased in the group with low-yielding RILs compared to the HGY group, suggesting that the processes of PSII in the low-yielding group were injured by drought more than in the high-yielding group. Accordingly, the high-yielding group exhibited a higher tolerance of the photosynthetic apparatus than the low-yielding group. This finding is in accordance with previous experiments on drought tolerance of wheat (Roostaei et al., 2011; Benani et al., 2016; Parihar \& Soni, 2016; Pour-Aboughadareh et al., 2019). The decrease in $F_{v} / F_{m}$ follows the chlorophyll content degradation, which impedes the photochemical process in the leaves (Tab. 2). Our results are consistent with the findings of Ahmadizadeh (2013) and Kalmatskaya et al. (2016), who reported that drought stress can deteriorate the plant's structure and inhibit the photochemical activity of PSII.

Changes in the chlorophyll fluorescence parameters of the durum wheat genotypes examined were revealed by means of a regression analysis under drought and irrigation conditions (Tab. 3, Fig. 1). The reduction of $F_{v} / F_{m}$ was found to be associated with chlorophyll concentration, thus affecting the processes of photosynthetic electron transport and photo-phosphorylation (Fracheboud \& Leipner, 2003; Zhuang et al., 2020). In non-stressed plants, the optimal level of $\mathrm{F}_{\mathrm{v}} / \mathrm{F}_{\mathrm{m}}$ is approximately 0.834 , which is considered essential for the plant's photosynthetic performance (Björkman \& Demmig, 1987). This discovery is in concordance with our results. However, the $F_{v} / F_{m}$ and CHLSPAD values obtained remained remarkably constant under irrigation conditions. The mean values of $F_{v} / F_{m}$ in the high- and low-yielding groups were similar ( 0.80 and 0.81 , respectively), whereas no significant difference was recorded in the chlorophyll contents (Tab. 2). The stability of the $\mathrm{F}_{\mathrm{v}} / \mathrm{F}_{\mathrm{m}}$ values indicates that the PSII of the high- and low-yielding groups is rather stable under supplemental irrigation compared to that recorded under drought conditions. Therefore, a higher defensive ability of PSII was found to be a significant mechanism of tolerance in the RILS considered.

Table 3. Regression parameters of fluorescence measurements for the grain yields of the wheat genotypes considered under drought and supplemental irrigation conditions during 2004 and 2005 seasons

\begin{tabular}{|c|c|c|c|c|c|c|}
\hline \multirow{2}{*}{ Parameter } & \multicolumn{3}{|c|}{ Drought } & \multicolumn{3}{|c|}{ Irrigated } \\
\hline & Intercept & Slopes & $\overline{\mathbf{R}^{2}}$ & Intercept & Slopes & $\overline{\mathbf{R}^{2}}$ \\
\hline$\overline{F_{0}}$ & $5643.93(\mathrm{P}<.0001)$ & $-2.83 \mathrm{P}=0.0011)$ & $0.53^{* * * \pi}$ & $5029.94(\mathrm{P}<.0001)$ & $1.29^{\mathrm{ns}}$ & $0.08^{\text {ns }}$ \\
\hline $\mathrm{F}_{\mathrm{m}}$ & $772.013 \mathrm{~ns}$ & $0.91(\mathrm{P}<.0001)$ & $0.13^{* * * *}$ & $5731.63(\mathrm{P}<.0001)$ & $0.03^{\text {ns }}$ & $0.003^{\mathrm{ns}}$ \\
\hline$F_{v}$ & $938.78(\mathrm{P}=0.0343)$ & $1.08(\mathrm{P}=0.0011)$ & $0.18^{* * * *}$ & $5821.3(\mathrm{P}<.0001)$ & $0.01^{\mathrm{ns}}$ & $0.000^{\mathrm{ns}}$ \\
\hline $\mathrm{F}_{\mathrm{v}} / \mathrm{F}_{\mathrm{m}}$ & $8230.29(\mathrm{P}<.0001)$ & $15071(\mathrm{P}<.0001)$ & $0.25^{* * *}$ & $6232.43 \mathrm{P}=0.0005)$ & $-485.73^{\mathrm{ns}}$ & $0.000^{\mathrm{ns}}$ \\
\hline Que & $6078.27(\mathrm{P}<.0001)$ & $-8938(\mathrm{P}<.0001)$ & $0.25^{* * * *}$ & $5783.05(\mathrm{P}<.0001)$ & $235.4^{\mathrm{ns}}$ & $0.000^{\mathrm{ns}}$ \\
\hline Lwp & $504.82 \mathrm{~ns}$ & $649(\mathrm{P}<.0001)$ & $0.22^{* * * *}$ & $6115.8(\mathrm{P}<.0001)$ & $-52.63^{\mathrm{ns}}$ & $0.002^{\mathrm{ns}}$ \\
\hline CHLSPAD & $4551.06(\mathrm{P}<.0001)$ & $-14.93 \mathrm{~ns}$ & $0.004 \mathrm{~ns}$ & $3046.52(\mathrm{P}<.0001)$ & $53.27(\mathrm{P}=0.0003)$ & $0.092^{* * *}$ \\
\hline
\end{tabular}



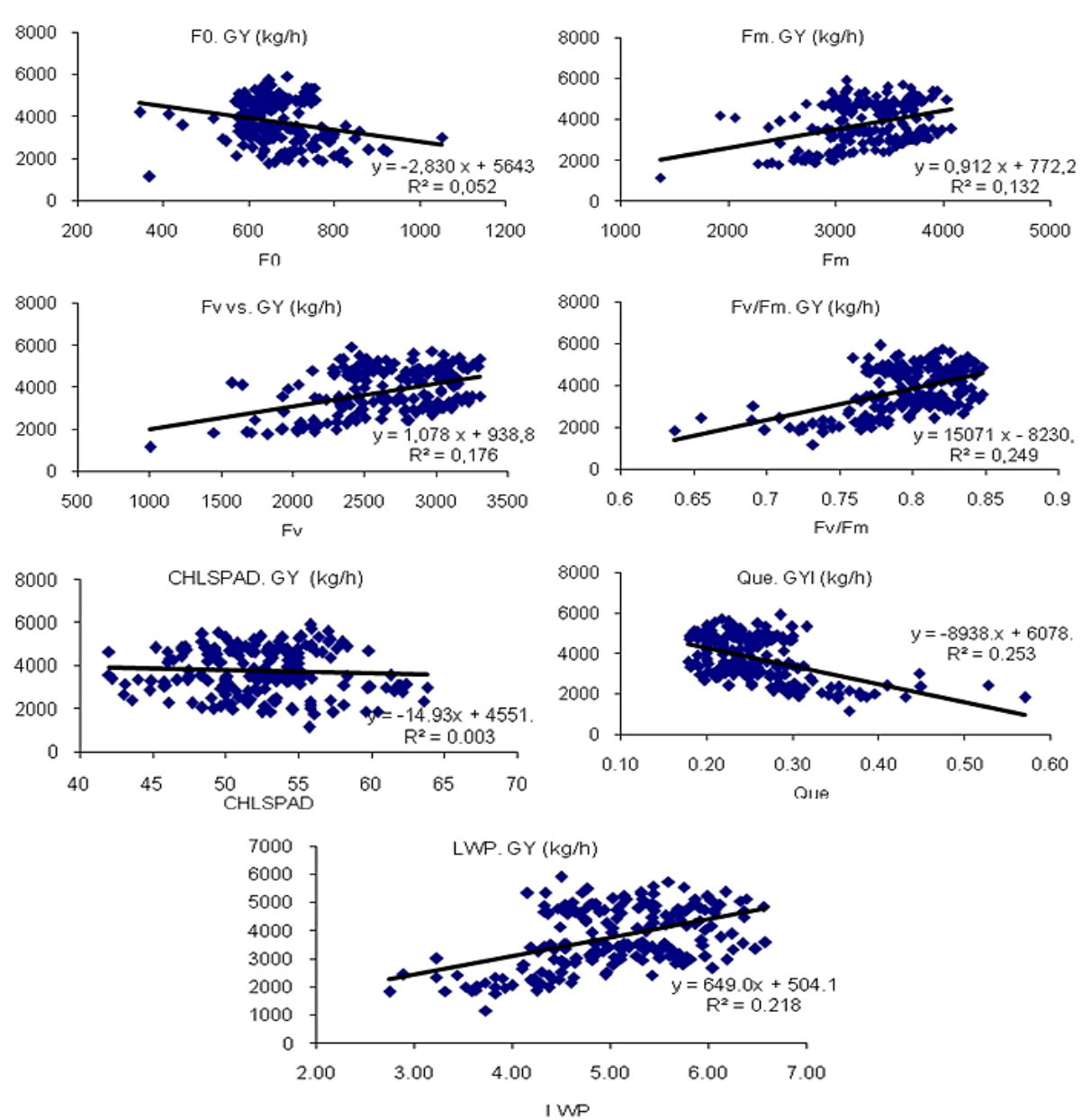

Figure1. Regression lines, data points, $\mathrm{R}^{2}$ values for the fluorescence parameters and grain yield under drought stress

Under drought conditions, the slopes obtained were highly significant $(\mathrm{P}<0.001)$ for all the fluorescence parameters examined, with the exception of the CHLSPAD parameter. The slopes exhibited positive values for the majority of parameters, with the exception of the $\mathrm{F}_{0}$ and Que parameters (Tab. 3). Furthermore, the regression analysis performed showed a decrease in the Que parameter (Fig. 1), which could probably be accounted for by the PSI system damage (Roostaei et al., 2011). Consequently, the Que reduction is linked to stress, which can adversely affect the use of photosynthetic energy and cause alterations to the transfer of electron in the PSII. The intercepts were also significant under drought conditions, with the exception of $F_{v}$ and Lwp. However, only the CHLSPAD parameter was significant under irrigated conditions $(P<0.001)$ (Tab. 2). Our results are consistent with the findings of Araus et al. (1998), and Mendez-Espinoza et al. (2019). As reported by Urban et al. (2017), water deficit can induce changes in the fluorescence parameters. The reduction in $\mathrm{Fv} / \mathrm{Fm}$ is associated with the reduction in photosynthetic products, which can disturb the mechanism of osmotic adjustment and the capacity of plants to cope with drought.

\section{CONCLUSION}

In general, our findings indicate that the slopes obtained for the fluorescence parameters considered under drought stress were more significant than those obtained under irrigation conditions. The differences between durum wheat genotypes tolerant and sensitive to water deficit stress are reported in this study. Chlorophyll fluorescence measurements during the grain filling stage were found useful for the evaluation of grain yield performance. The fluorescence parameters $\mathrm{F}_{0}, \mathrm{~F}_{\mathrm{m}}$ and $\mathrm{F}_{\mathrm{v}} / \mathrm{F}_{\mathrm{m}}$ are specific physiological indices of the photo-inhibition of photosynthesis under drought conditions. They have a direct or indirect impact on the performance of the yield under the Mediterranean conditions. The use of physiological traits such as fluorescence can facilitate the selection of durum 
wheat lines to improve the grain yield. They can also be used as additional indicators in screening wheat germplasm for drought tolerance.

\section{REFERENCES}

Abdipur M., Ramezani H.R., Bavei V., Talaee S. (2013): Effectiveness of canopy temperature and chlorophyll content measurements at different plant growth stages for screening of drought tolerant wheat genotypes. American-Eurasian Journal of Agricultural \& Environmental Sciences, 13(10): 1325-1338.

Abou-Elwafa S.F. (2016): Association mapping for yield and yield-contributing traits in barley under drought conditions with genome-based SSR markers. Comptes Rendus Biologies, 339: 153-162.

Ahmadizadeh M. (2013): Physiological and Agro-Morphological Response to Drought Stress. Middle-East Journal of Scientific Research, 13(8): 998-1009.

Allahverdiyev T.I., Talai J.M., Huseynova I.M., Aliyev J.A. (2015): Effect of drought stress on some physiological parameters, yield, yield components of durum (Triticum durum desf.) and bread (Triticum aestivum L.) wheat genotypes. Ekin Journal of Crop Breeding and Genetics, 1: 50-62.

Almeselmani M. (2012): Physiological Parameters for Evaluating Drought Tolerance in Durum Wheat Varieties Grown in the Fields in Syria. Journal of Biology and Today's World, 1(2): 53-63.

Almeselmani M., Saud A., Al-Zubi K., Abdullah F., Hareri F., Nassan M., Ammar M.A., Kanbar O. (2012): Physiological Performance of Different Durum Wheat Varieties Grown Under Rainfed Condition. Global Journal of Science Frontier Research Agriculture \& Biology, 12 (1): 55-63.

Almeselmani M., Al-Razak Saud A., Al-Zubi k., Al-Ghazali S., Hareri F., Al-Nassan M., Ammar M.A., Al-Nator A., Al-Gazawy A., Da Silva T. J.A. (2015): Evaluation of Physiological Traits, Yield and Yield Components at Two Growth Stages in 10 Durum Wheat Lines Grown Under Rainfed Conditions in Southern Syria. Cercetări Agronomiceîn Moldova, 2(162): $29-49$.

Anjum S.A., Xie X.Y., Wang L.C., Saleem M.F., Man C., Lei W. (2011): Morphological, physiological and biochemical responses of plants to drought stress. African Journal of Agricultural Research, 6(9): 2026-2032.

Araus J.L., Amaro T., Voltas J., Nakkoul H., Nachit M.M. (1998): Chlorophyll fluorescence as a selection criterion for grain yield in durum wheat under Mediterranean conditions. Field Crops Research, 55: 209-223.

Avenson T.J., Cruz J.A., Kanazawa A., Kramer D.M. (2005): Regulating the Proton Budget of Higher Plant Photosynthesis. Proceedings of the National Academy of Sciences of the United States of America, 102: 9709-9713.

Baker N.R., Oxborough K., Lawson T., Morison J.I.L. (2001): High resolution imaging of photosynthetic activities of tissues cells and chloroplasts in leaves. Journal of Experimental Botany, 52: 615-621.

Baker N.R. \& Rosenqvist E. (2020): Applications of chlorophyll fluorescence can improve crop production strategies: an examination of future possibilities. Journal of Experimental Botany, 71 (4): 1647.

Balouchi H.R. (2010): Screening Wheat Parents of Mapping Population for Heat and Drought Tolerance, Detection of Wheat Genetic Variation. World Academy of Science, Engineering and Technology International Journal of Nuclear and Quantum Engineering, 4(1): 63-73.

Bennani S., Nsarellah N., Birouk A., Ouabbou H., Tadesse W. (2016): Effective Selection Criteria for Screening Drought Tolerant and High Yielding Bread Wheat Genotypes. Universal Journal of Agricultural Research, 4(4): 134-142.

Bijanzadeh E. \& Emam Y. (2010): Effect of defoliation and drought stress on yield components and chlorophyll content of wheat. Pakistan Journal of Biological Sciences, 14(15): 699-705.

Bjorkman O. \& Demmig B. (1987): Photon Yield of $\mathrm{O}_{2}$ Evolution and Chlorophyll Fluorescence Characteristics at $77 \mathrm{~K}$ among Vascular Plants of Diverse Origins. Planta, 170: 489-504.

Bogale-Gonfa A., Kindie T., Tilahun G. (2011): Morphological and physiological attributes associated to drought tolerance of Ethiopian durum wheat genotypes under water deficit. Journal of Biodiversity and Environmental Sciences, 1(2): 22-36.

Boussakouran A., Sakar E.H., El Yamani M., Rharrabti Y. (2019): Morphological Traits Associated with Drought Stress Tolerance in Six Moroccan Durum Wheat Varieties Released Between 1984 and 2007. Journal of Crop Science and Biotechnology, 22 (4): 345-353.

Dabrowski A.H., Baczewska B., Pawluśkiewicz M., Paunov P., Alexantrov V., Goltsev V., Kalaji. M.H. (2016): Prompt chlorophyll $a$ fluorescence as a rapid tool for diagnostic changes in PSII structure inhibited by salt stress in Perennial ryegrass. Journal of Photochemistry and Photobiology B: Biology, 157: 22-31.

Dolferus R., Ji X., Richards R.A. (2011): Abiotic stress and control of grain number in cereals. Plant Science, 181: $331-341$.

Ehdaie B., Alloush G.A., Madore M.A., Waines J.G. (2006): Genotypes Variation for Stem Reserves and Mobilization in Wheat. I. Postanthesis Changes in Internode Dry Matter. Crop Science, 46: 735-746.

Etminan A., Pour-Aboughadareh A., Mohammadi R., Shoshtari L., Yousefiazarkhanian M., MoradkhaniH. (2019): Determining The Best Drought Tolerance Indices Using Artificial Neural Network (ANN). Insight Into Application of Intelligent Agriculture in Agronomy and Plant Breeding. Cereal Research Communications, 47: 170-181.

Farooq M., Wahid A., Kobayashi N., Fujita D., Basra S. (2009): Plant drought stress: effects, mechanisms and management. Agronomy for Sustainable Development, Springer, 29(1): 185-212. 
Farshadfar E., Elyasi P., Hasheminasab H. (2013): Incorporation of Agronomic and Physiological Indicators of Drought Tolerance in a Single Integrated Selection Index for Screening Drought Tolerant Landraces of Bread Wheat Genotypes. International Journal of Agronomy and Plant Production, 4: 3314-3325.

Federer W.T. (1956): Augmented Designs. Howaiian planters, Record, 141-144.

Feng W., Qi S., Heng Y., Zhou Y., Wu Y., Liu W., He L., Xiao Li X. (2017): Canopy Vegetation Indices from in situ Hyperspectral Data to Assess Plant Water Status of Winter Wheat under Powdery Mildew stress. Frontiers in Plant Science, 8(1219): 1-18.

Fracheboud Y. \& Leipner J. (2003): The Application of Chlorophyll Fluorescence To Study Light, Temperature, and Drought Stress. Practical Applications of Chlorophyll Fluorescence in Plant Biology, Deell, J.R. and Tiovonen, P.M.A., Eds., Boston, 125-150.

Fotovat R., Valizadeh M., Toorchi M. (2007): Association between water-use efficiency components and total chlorophyll content (SPAD) in wheat (Triticum aestivum L.) under well-watered and drought stress conditions. Journal of Food, Agriculture and Environment, 5: 225-227.

Ghobadi M., Khosravi S., Kahrizi D., Shirvani F. (2011): Study of Water Relations, Chlorophyll and Their Correlations with Grain Yield in Wheat (Triticum aestivum L.) Genotypes. International Journal of Agricultural and Biosystems Engineering, 5(6): 353-356.

Guerfel M., Baccouri O., Boujnahb D., Cha1 bi W., Zarrouk M. (2009): Impacts of water stress on gas exchange, water relations, chlorophyll content and leaf structure In the two main Tunisian olive (Olea europea L.) cultivars. Scientia Horticulturae, 119: 257- 263.

Guha A., Sengupta D., Reddy A.R. (2013): Polyphasic chlorophyll a fluorescence kinetics and leaf protein analyses to track dynamics of photosynthetic performance in mulberry during progressive drought. Journal of Photochemistry and Photobiology B: Biology, 119: 71-83.

Goltsev V.N., Kalaji M.H., Paunov M., Bąba W., Horaczek T., Mojski J., Kociel H., Allakhverdiev S.I. (2016): Variable chlorophyll fluorescence and its use for assessing physiological condition of plant photosynthetic apparatus. Russian Journal of Plant Physiology, 63(6): 869-893.

González -Ribot G., Opazo., Silva P., Acevedo E. (2017): Traits Explaining Durum Wheat (Triticum turgidum L. spp. Durum) Yield in Dry Chilean Mediterranean Environments. Frontiers in Plant Science, 8: 1781.

Habash D.Z., Kehel Z., Nachit M.M. (2009): Genomic approaches for designing durum wheat ready for climate change with a focus on drought. Journal of Experimental Botany, 60: 2805-2815.

Havaux M., Emez M., Lannoye R. (1998): Sélection de Variétés de Blé Dur (Triticum durum Desf.) et de Blé Tender (Triticum aestivum L.) Adaptation la sécheresse par Ia mesure de l'extinction de la Fluorescence de la Chlorophylle in Viva. Agronomie, 8(3): 193-199.

Honsdorf N., March T.J., Pillen K. (2017): QTL controlling grain filling under terminal drought stress in a set of wild barley introgression lines. PLOS ONE, 12(10):1-18.

Izanloo A., Condon A.G., Langridge P., Tester M., Schnurbusch T. (2008): Different mechanisms of adaptation of cyclic water stress in two South Australian bread wheat cultivars. Journal of Experimental Botany, 59: 3327-3346.

Jedmowski C., Ashoub A., Brüggemann W. (2013): Réactions des variétés locales égyptiennes de Hordeum vulgare et Sorghum bicolor au stress de sécheresse, évaluées par l'analyse transitoire de fluorescence OJIP. Acta Physiologiae Plantarum, 35: 345-354.

Kalaji H.M., Carpentier R., Allakhverdiev S.I., Bosa K. (2012): Fluorescence parameters as early indicators of light stress in barley. Journal of Photochemistry and Photobiology B: Biology, 112: 1-6.

Kalaji H.M., Jajoo A., Oukarroum A., Brestic M., Zivcak M., Samborska I.A., Magdalena D.C., Lukasik I., Goltsev V., Ladle R.J. (2016): Chlorophyll a fluorescence as a tool to monitor physiological status of plants under abiotic stress conditions. Acta Physiologiae Plantarum, 38(102): 1-11.

Kalmatskaya O., Karavaev A. V., Gunar L. (2016): Fluorescent Indices of Oak and Wheat Leaves in Dependence on Chlorophyll Content. In: Third International Symposium on Optics and Biophotonics and Seventh Finnish-Russian Photonics and Laser Symposium (PALS), Saratov, 9917: 153-158.

Khadka K., Earl H.J., Aizada M.N., Alireza Navabi A. (2020): A Physio-Morphological Trait-Based Approach for Breeding Drought Tolerant Wheat. Frontiers in Plant Science, 11: 715.

Khayantnezhad M., Zaeifizadeh M., Gholamin R. (2011): Effect of end-season drought stress on chlorophyll fluorescence and content of antioxidant enzyme superoxide dismutase enzyme (SOD) in susceptible and tolerant genotypes of durum wheat. African Journal of Agricultural Research, 6(30): 6397-6406.

Liu H., Searle L.R., Mather., Able D.E., Able J.A. (2015): Morphological, physiological and yield responses of Durum Wheat to pre-anthesis water-deficit stress are genotype-dependent. Crop Pasture Sci, 66(10): 1024-1038

Liu H., Able A.J., Able, J.A. (2017): Genotypic water-deficit stress responses in durum wheat: Association between physiological traits, micro RNA regulatory modules and yield components. Functional Plant Biology, 44: 538-551.

Maccaferri M., Sanguineti M.C., Corneti S., Araus J.L., Ben Salem M., Bort J., De Ambrogio E., Garcia del Moral L.F., Demonti A., El-Ahmed A., Maalouf F., Machlab H., Martos V., Moragues M., Motawaj J., Nachit M., Nesrallah N., Ouabbou H., Royo C., Slama A., Tuberosa R. (2008): Quantitative Trait Loci for Grain Yield and Adaptation of Durum Wheat (Triticum durum Desf). Across a Wide Range of Water Availability. Copyright by the Genetics Society of America, 178: 489-511.

Mendez-Espinoza A.M., Romero-Bravo S., Estrada F., Garriga M., Lobos G.A., Castillo D., Matus I., Aranjuelo I., Del Pozo 
A. (2019): Effects of Pre-Anthesis Drought, Heat and Their Combination on the Growth, Yield and Physiology Diverse Wheat (Triticum aestivum L.) Genotypes Varying in Sensitivity to Heat and Drought Stress. Frontiers in Plant Science, 10(404): 1-16.

Mohammadi R, Etminan A., Shoshtari L. (2018): Agro-physiological Characterization of Durum Wheat Genotypes under Drought Conditions. Experimental Agriculture, 55 (3): 484-499.

Mohammadi H., Mohammadi M.J., Sabaghnia N. (2019): Chlorophyll Fluorescence response of Wheat to Exogenous Application of growth regulators under terminal drought stress. Pobrane z czasopismaAnnales C-Biologia, 1: 1-15.

Nori A., Ahmadizadeh M., Shahbazi H., Aharizad S. (2011): Evaluation of Physiological Responses of Durum Wheat Landraces (Triticum Durum L.) to Terminal Drought Stress. Advances in Environmental Biology, 5(7): 1947-1954.

Oxborough K. (2004): Imaging of Chlorophyll a Fluorescence: Theoretical and Practical Aspects of an Emerging Technique for the Monitoring of Photosynthetic Performance. Journal of Experimental Botany, 55: 1195-1205.

Paknejad F., Nasri M., Reza H., Moghadam T., Zahedi H., Alahmadi M.J. (2007): Effects of Drought Stress on Chlorophyll Fluorescence Parameters, Chlorophyll Content and Grain Yield of Wheat Cultivars. Journal of Biological Sciences, 7(6): 841-847.

Papageorgiou G.C. \& Govindjee (2011): Photosystem II Fluorescence: Slow changes Đ Scaling from the Past. Journal of Photochemistry and Photobiology B, 104(1-2): 258-270.

Parihar S. \& Soni V. (2016): Biophysical Characterization of Drought Tolerance in Wheat (Triticum aestivum. L.)Through Polyphasic Chlorophyll Fluorescence OJIP analysis. Biotechnological Research, 2(1): 48-52.

Paunov M., Koleva L., Vassilev A., Vangronsveld J., Goltsev V. (2018): Effects of Different Metals on Photosynthesis: Cadmium and Zinc Affect Chlorophyll Fluorescence in Durum Wheat. International Journal of Molecular Sciences, $19(3): 787$.

Peterson R.G. (1985): Augmented Desings for preliminary yield trials (revised), Rachis, 4: 27-32.

Pfeiffer W.H., Sayre K.D., Reynolds M.P. (2000): Enhancing genetic grain yield potential and yield stability in durum wheat, In Options Mediterraneennes, Serie A, Seminaires Mediterraneens, 40: 83- 93.

Pour-Aboughadareh A., Mansoor Omidi M., Mohammad Reza Naghavi M.R., Etminan A., Ali Ashraf Mehrabi A.A., Peter Poczai P., Bayat H. (2019): Effect of Water Deficit Stress on Seedling Biomass and Physio-Chemical Characteristics in Different Species of wheat Possessing the D genome. Agronomy, 9(522): 1-20.

Pour-Aboughadareh A., Mohammadi R., Etminan A., Lia Shooshtari E.A., Maleki-Tabrizi N., Poczai P. (2020): Effects of Drought Stress on Some Agronomic and Morpho-Physiological Traits in Durum Wheat Genotypes. Journal Sustainability, 12(5610): 1-15.

Qaseem M.F., Qureshi R., Shaheen H. (2019): Heat and Their Combination on The Growth, Yield and Physiology of Diverse Wheat (Triticum aestivum L.) Genotypes Varying in Sensitivity to Heat and Drought Stress. Scientific Reports, 9(6955): $1-12$.

Roostaei M., Mohammadi S.A., Amri A., Majidi E., Nachit M., Haghparast R. (2011): Chlorophyll Fluorescence Parameters and Drought Tolerance in a Mapping Population of Winter Bread Wheat in the Highlands of Iran. Russian Journal of Plant Physiology, 58(2): 351-358.

Schansker G., Toth S.Z., Holzwarth A.R., Garab G. (2014): Chlorophyll a fluorescence: Beyond the limits of the QA model. Photosynthetic Research, 120(1-2): 43-58.

Schreiber U., Schliwa U.W., Bilger W. (1986): Continuous Recording of Photochemical and Non-photochemical Chlorophyll Fluorescence Quenching With a New Type of Modulation Fluorometer. Photosynthesis Research, 10(1-2): 51-62.

Siddique M.R.B., Hamid A., Islam M.S. (2000): Drought stress effects on water relations of wheat. Botanical Bulletin of Academia Sinica, 41: 35-39.

Simeneh T.A. (2020): Photosynthesis limiting stresses under climate change scenarios and role of chlorophyll fluorescence. Cogent Food \& Agriculture, 6: 1-18.

Stirbet, A., Lazár, D., Kromdijk, J., Govindjee, G. (2018): Chlorophyll fluorescence induction: Can just a - one second measurement be used to quantify a biotic stress response? Photosynthatica, 1(56): 86-104.

Sukumaran S., Reynolds M.P., Sansaloni C. (2018): Genome-Wide Association Analyses Identify QTL Hotspots for Yield and Component Traits in Durum Wheat Grown under Yield Potential, Drought, and Heat Stress Environments. Frontiers in Plant Science, 9(81): 1-16.

Talebi R., Fayaz F., Naji A.M. (2009): Effective Selection Criteria for Assessing Drought Stress Tolerance in Durum Wheat (Triticum durum Desf.). General and Applied Plant Physiology, 35(1-2): 64-74.

Talebi R. (2011): Evaluation of Chlorophyll Content and Canopy Temperature as Indicators for Drought Tolerance in Durum Wheat (Triticum durum Desf.). Australian Journal of Basic and Applied Sciences, 5(11): 1457-1462.

Tardieu F., Parent B., Caldeira C.F., Welcker C. (2014): Genetic and physiological controls of growth under water deficit. Plant Physiology, 164: 1628-1635.

Urban L., Aarrouf J., Luc P.R., Bidel L.P.R. (2017): Assessing the Effects of Water Deficit on Photosynthesis Using Parameters Derived from Measurements of Leaf Gas Exchange and of Chlorophyll Fluorescence. Frontiers in Plant Science, 8(2068): 1-18.

Wang X., Wang L., Shangguan Z. (2016): Leaf Gas Exchange and Fluorescence of Two Winter Wheat Varieties in Response to Drought Stress and Nitrogen Supply. PLoS ONE, 11(11): 1-15.

Yu T.F., Xu T.S., Guo J.K., WangY.X., Fu J.D., Chen X., Zhou Y.B., Chen M., Ye X.G., Ma Y.Z. (2017): Improved drought tolerance in wheat plants over expressing a synthetic bacterial cold shock protein gene. SeCspA. Scientific Reports, 7(44050): 1-14. 
Zadoks J.C., Chang T.T., Konzak C. F. (1974): A decimal code for the growth stages of cereals. Weed Research, 14: 415-421.

Zhuang J., Wang Y., Chi Y., Zhou L., Chen J., Zhou W., Song J., Zhao N., Ding J. (2020): Drought Stress Strengthens The Link Between Chlorophyll Fluorescence Parameters and Photosynthetic Traits. PeerJ, 8: 1-20.

Submitted: 10.01.2021.

Accepted: 25.05.2021. 